\title{
The Impact of a Large City on Land Use in Suburban Area - The Case of Wrocław (Poland)
}

\author{
Katarzyna Tokarczyk-Dorociak ${ }^{1 *}$, Jan Kazak², Szymon Szewrański² \\ 1 Institute of Landscape Architecture, Wrocław University of Environmental and Life Sciences, Grunwaldzka St. \\ 55, 50-357 Wrocław, Poland \\ 2 Department of Spatial Economy, Wrocław University of Environmental and Life Sciences, Grunwaldzka St. 55, \\ 50-357 Wrocław, Poland \\ * Corresponding author's e-mail: katarzyna.tokarczyk-dorociak@upwr.edu.pl
}

\begin{abstract}
Land use and the landscape of the suburban area are strongly affected by the impact of a large city, which is an important factor determining their development. The paper presents the results of analyses of the functional and spatial transformations depending on the distance from city limits and main access roads. The analyses were based on CORINE data for the years: 1990, 2000 and 2006. The spatial transformations in the specified distance buffers were described with use of the indicator of the share of specific land use areas in the total surface area and the indicator of the average landscape patch surface area. The conducted analyses confirm that the spatial patterns characteristic for suburbanisation exist in the vicinity of large cities and along access roads. The phenomena noticed in the suburban zone of Wrocław include, among others, an increased share of surface area used for residential purposes, a decreased area of arable lands, and an increased concentration of commercial and industrial areas in the direct proximity of the city and access roads.
\end{abstract}

Keywords: land use, suburban area, indicator-based assessment

\section{INTRODUCTION}

The change in the manner of land management in the areas located in the vicinity of cities has been witnessed for centuries. The development of areas near fortifications led to the emergence of medieval cities. The current metropoles have developed through the expansion of towns to adjacent areas and transformed their use into urban forms. We are still witnessing the spreading of cities onto areas located beyond their limits. Due to various reasons, residential areas as well as commercial and industrial zones develop in these areas. The fact that it is attractive to locate residential buildings in suburban areas results from such factors as the proximity of the work place, convenient transportation routes, and favourable natural conditions. Another important factor is the low price of building plots (Szachowicz, Niedźwiecka-Filipiak 2007; Staszewska 2012).
These processes are mainly caused by the willingness to improve the quality of life the residents living in large urban centres, which is an important research topic recognised throughout the world (Przybyła et al. 2014). While deciding on the location of their new investments, the industrial and service companies take into account the real estate prices, access to sufficiently large areas of land, lower likelihood of conflict with the neighbours in the event of operations constituting nuisance and easy access to highly qualified staff (whose number is higher in academic centres located in large central cities). This is the socalled economic suburbanisation that refers to the $2^{\text {nd }}$ and $3^{\text {rd }}$ sectors of the economy (Zathey 2005). Another important aspect of the suburbanisation process are the social conflicts that result from the differences between the lifestyles of "old-timers" and "newcomers" in suburban areas (Kajdanek, 2014), which also manifest themselves in dif- 
ferent ways of land management. As a result of such anthropogenic activity, suburban areas are subject to significant transformations and quite often to degradation.

The city expansion processes have a considerable influence on the land usage structure and the landscape of rural areas. This results from many centuries of interactions between the natural and anthropogenic conditions. Currently, the main factor that affects the landscape of suburban areas is the demand for a specific way of land management. In this case, it is connected with the impact of the city and the search for areas where residential and industrial facilities may be located. Demand is the most important factor influencing the spatial changes, as it adds value to space (Cymerman, 2012). For the municipalities that manage suburban areas, changing the designation of agricultural land into service, industrial or residential areas has been and remains a form of increasing budget revenues. Uncontrolled transformations of land usage and thus of the landscape of areas affected by agglomerations may cause certain negative consequences for the society and environment in the future. A major threat for sustainable spatial management is the popular view stating that optimum space use is commonly defined as such usage that generates the highest economic value of space among all physically possible and legally acceptable forms of use (Bajerowski 2008).

Currently, the town-planning shape of the suburban zone is determined by: planning guidelines (local spatial development plan or decision on the conditions of building and site development), ownership titles, economic and cultural factors. As far as the city life cycle is concerned, suburbanisation is a process that leads to eventual degradation of the structure and landscape of rural areas (Przesmycka, 2012). In order to mitigate the negative influence of suburbanisation on the values of suburban areas it is necessary to apply certain solutions to support local authorities in efficient and sustainable spatial management. This is enabled, among others, by quantified analyses of the changes in land usage structure and by setting development goals for local self-governments. The research on the impact of large cities on suburban areas may be effectively supported by indicatorbased analysis illustrating the transformations in the functional and spatial structure. The analysis of phenomena that occur in the urban or suburban areas should also take into account both the tem- poral and spatial aspects of the occurring changes (Świąder et al., 2016). Such approach reflects the functional and spatial transformations better and thus allows for a more precise evaluation of processes. The analysis of the neighbourhood of areas subject to spatial transformations is currently the topic of scientific research, and the results of neighbourhood impact analyses enable the modelling of future spatial changes that result both from the natural environment forming processes and human interference with the spatial structure (Wang et al., 2017).The calculation and application of indicators in spatial management practice may be utilitarian by means of their implementation in local evaluation models and decision support systems (Kazak et al., 2017; 2018).

\section{OBJECTIVE OF THE STUDY}

The aim of the study was to verify how the two determining factors that support the functional and spatial transformations in the suburban zone of a large city influence changes in landscape. These determining factors include the distance from the central city limits and the distance from the main routes that guarantee communication between suburban areas and the city centre.

\section{TEST AREA}

The research area (Figures 1 and 2) consists of ten municipalities located within the impact zone of Wrocław, where suburbanisation-related changes have been noticed (Szewrański et al., 2015). They include three urban and rural municipalities (Kąty Wrocławskie, Siechnice and Oborniki Śląskie) and seven rural municipalities (Kobierzyce, Żórawina, Czernica, Długoręka, Wisznia Mała, Miękinia, and Kostomłoty). Eight of these municipalities are directly adjacent to Wrocław, while two others are located in the nearest proximity (up to five kilometres away). In administrative terms, the analysed area belongs to four counties: the Wrocław county, a part of the Wroclaw county, a part of the Trzebnica county and of the Środa county. The areas shown in Figures 1 and 2 (marked in shades of green) have been subjected to analyses conducted in the distance buffer zones from the limits of Wrocław and from main access roads. The research area is characterised by diversified natural conditions. 


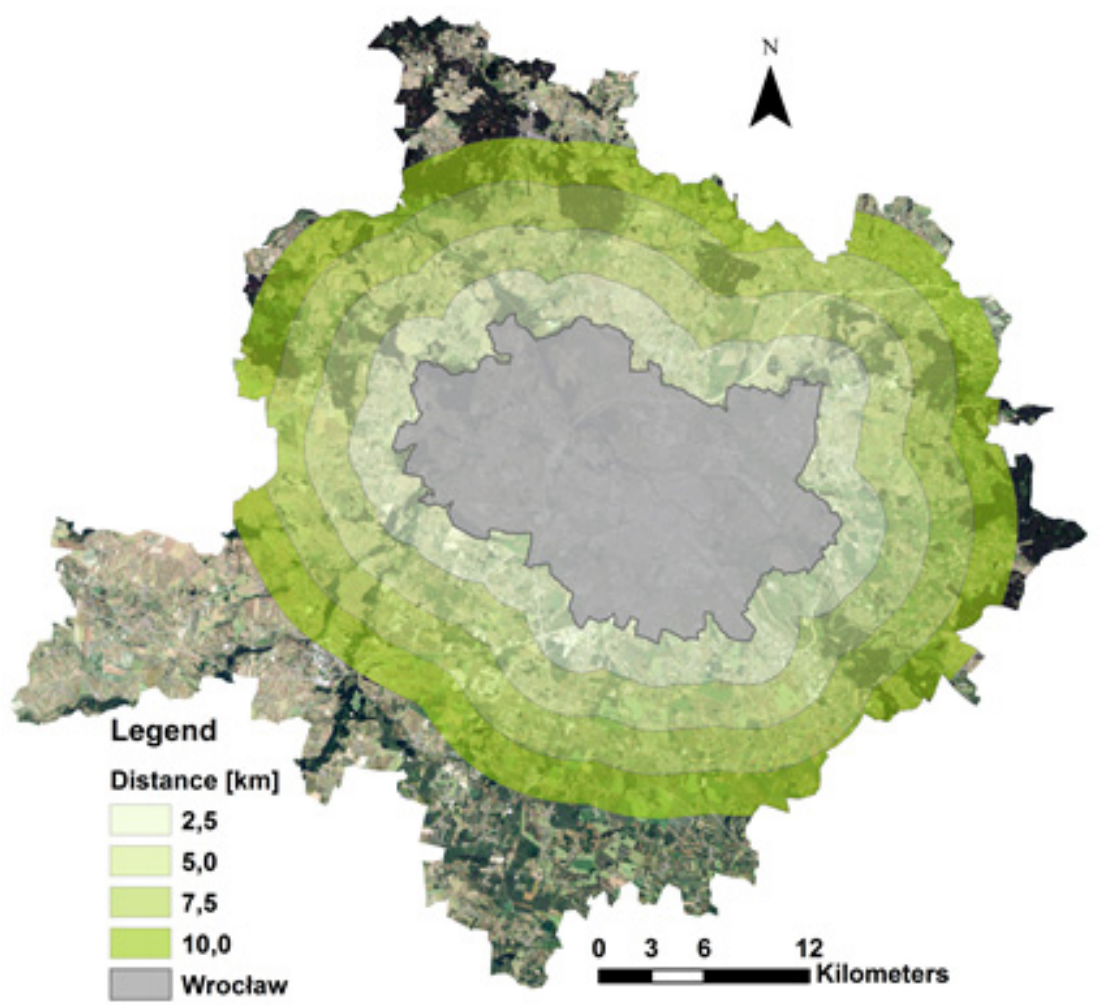

Fig. 1. Buffers established at $2.5 \mathrm{~km}$ intervals from the administrative limits of Wrocław in the territory of suburban municipalities

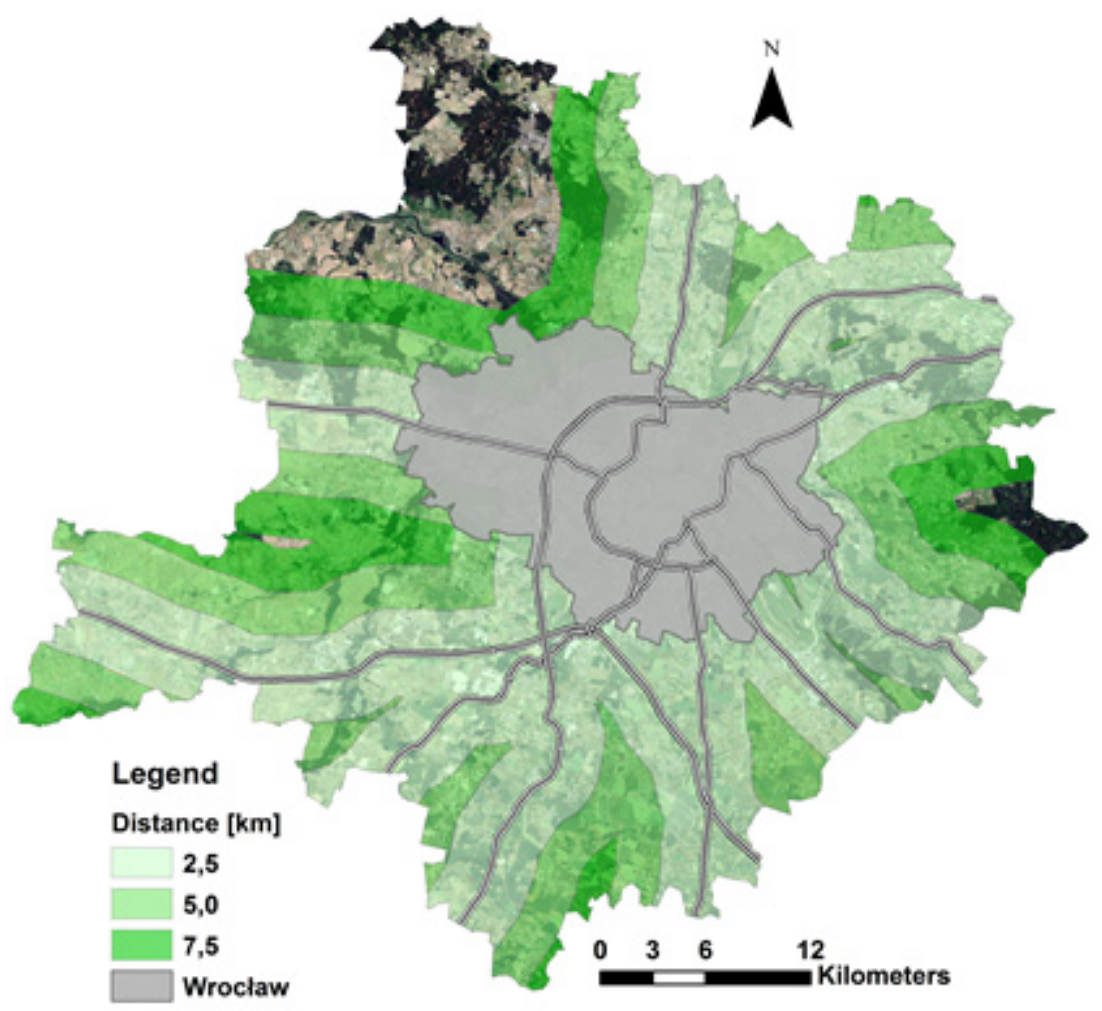

Fig. 2. Buffers established along main access roads to Wrocław 
It covers river valleys (of the Oder, Oława, Bystrzyca, Widawa and Ślęza Rivers), and lowlands, while part of the analysed area is located in the Trzebnickie Hills. Due to high natural values that exist mainly in the river valleys, the area is subject to various forms of nature conservation.

\section{METHODOLOGY}

The starting point for the selection of the research method was the central place theory that seeks to explain the patterns of number, size and location of human settlements in an urban system (Christaller 1993). As the central point, the theory assumes that there is a strong connection between the distance from the main centre and the formation of specific forms of spatial management at certain distances. The analyses of the influence of distance from the central city and from communication routes on the spatial and landscape changes were conducted in the buffer zones of these objects. Initially, 10 and 7 buffer zones were established around the city Wroclaw and access roads, respectively, at $2.5 \mathrm{~km}$ intervals. However, only 4 zones around the limits of Wrocław (Fig. 1) and 3 distance zones along main access roads (Fig. 2) were selected for analysis. The number of analysed buffers depended on the possibility to establish full zones within the administrative borders of the analysed area.

In the buffers determined in this way, the changes in the share of specific types of land cover were analysed, i.e. cthe hanges in the surface area of residential, commercial and service development, as well as the changes in the share of arable land and grasslands. The share of areas with a specific type of land use is an indicator that is useful for the determination of the degree of landscape synanthropisation and of the tendencies in the spatial development of suburban zones. The second indicator used was the mean landscape patch size (MPS). MPS is calculated as the quotient of the total surface area of all patches in the analysed space and their number. This indicator illustrates the sizes of patches (both in reference to all patches and to patches with a given type of land use), which allows for an indirect evaluation of the degree of landscape fragmentation ${ }^{1}$. The

\footnotetext{
1 Due to the unequal size of zones (non-uniform samples) in the analyses of distance zones from the city limits and from main access roads, the mean patch size indicator was referred to the surface area of the zone (buffer).
}

calculations were performed for all types of land use and, separately, for built-up and arable land. The analyses were based on CORINE data for the years: 1990, 2000 and 2006.

\section{RESULTS}

\section{Changes in the landscape indicators depending on the distance from the administrative limits of the central city}

The first analysed factor determining the functional and spatial changes in the suburban zone of a large city is the distance from its administrative limits. The diagrams below illustrate the share of residential, industrial and commercial development (Fig. 3), arable land and grasslands (Fig. 4) in the total surface area of individual zones.

The residential zones are developing the most and they account for the highest share in the zone in buffers located at the closest distance from city limits (up to $2.5 \mathrm{~km}$ ). In the first zone, their share in the total area increased by approx. $2 \%$. Industrial and commercial facilities exist in all zones, with the relatively highest share in the zone 2.5 to $5 \mathrm{~km}$ away from the city limits. As far as industrial and service facilities are concerned, the share of this type of land use increased noticeably with time in all zones. A significant increase in such land use was noted in the fourth zone, located between 7.5 and $10 \mathrm{~km}$ away from Wrocław city limits. The first zone also experienced a rapid growth, as the share of this type of development has increased nearly four times in the last 16 years.

Although a major part of the areas around Wrocław is covered by arable land, their share increases considerably with the distance from the city. The lowest share of arable land can be found in the direct vicinity of the city (up to $2.5 \mathrm{~km}$ ), and then it increases dramatically with distance. Initial analyses demonstrate that farther than 25 $\mathrm{km}$ from the city limits arable land accounts for nearly $100 \%$ of the surface area. In comparison to arable lands, grasslands have a minor share in the surface of the analysed area, especially as the distance from the Wroclaw city limits increases. The majority of grasslands can be found in the zone up to $2.5 \mathrm{~km}$. This results from the residential development, which is usually surrounded by green areas. A clear trend in the area of grasslands, decreasing with time has been noted in the 

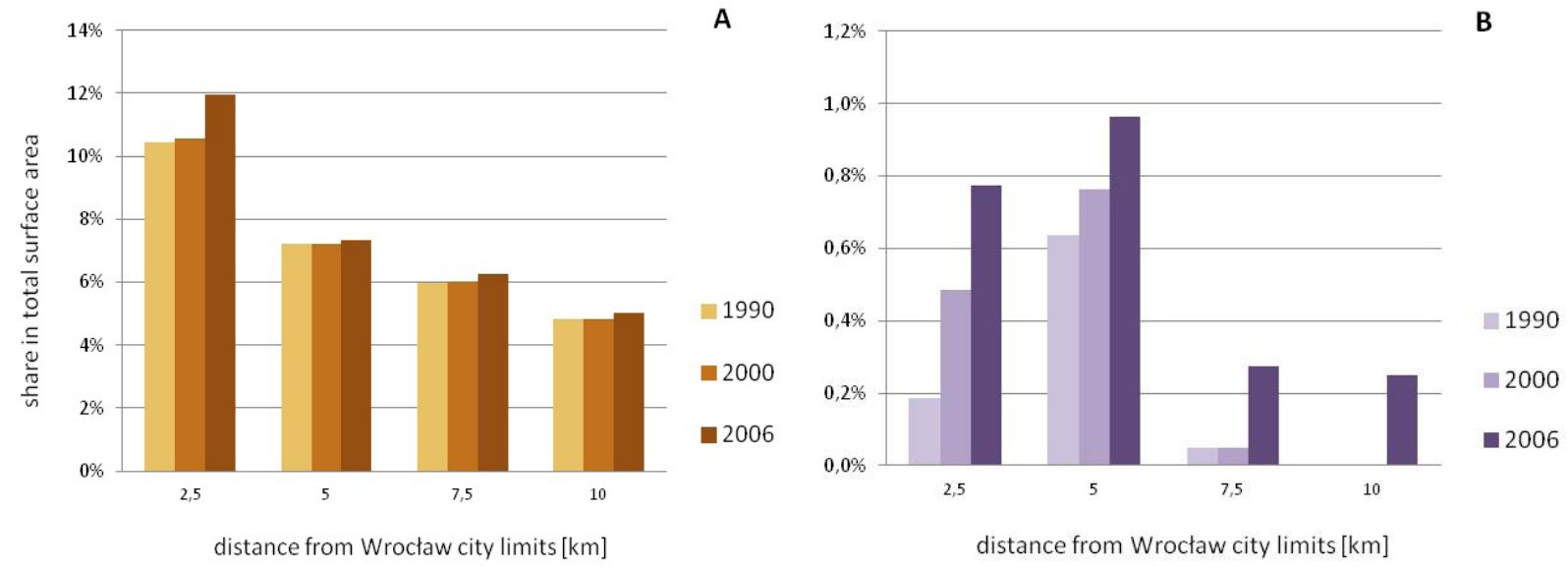

Fig. 3. Share of low intensity residential development areas (A) and industrial and service zones (B) in the total surface area of zones located at specific distances from the administrative limits of the city Wrockaw in the years 1990, 2000 and 2006
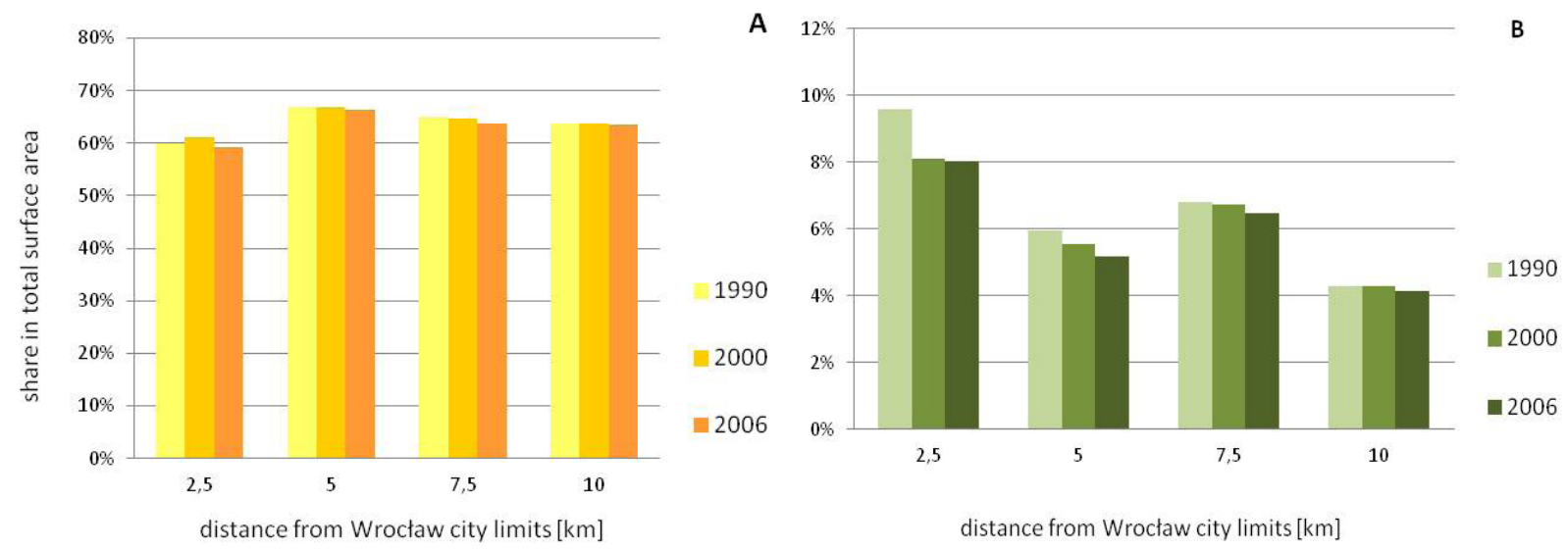

Fig. 4. Share of arable land (A) and grasslands (B) in the total surface area of zones located at specific distances from the administrative limits of the city Wrockaw in the years 1990, 2000 and 2006

presented 4 zones of distance from the city. This phenomenon is most visible in the zone directly adjacent to the city. A decrease both in the area of arable land and grassland has been noticed in three zones located closest to the city. This means that urbanisation processes occur at the expense of these types of land use.

The MPS indicator was also analysed for the designated buffer zones. Its value was calculated both for all landscape patches divided according to their distance from the city (Fig. 5), and, separately, for developed land and arable land (Fig. 6).

The value of this indicator increases considerably with growing distance from the city. This indicates that landscape patches (the surface area occupied by a single type of land use) are the smallest in the vicinity of the city (up to $2.5 \mathrm{~km}$ away from the city limits), which means that the fragmentation of landscape is stronger.
The size of patches increases with the growing distance from the city. In the last analysed zone (10 km away from the city) a considerable reduction in the MPS indicator was noted. This may result from the fact that the mosaic properties of landscape (smaller surface areas of developed land and more fragmented areas of arable land) are the strongest. This is also confirmed by the MPS indicator calculated separately for arable land.

The analysis of the MPS indicators calculated for specific types of land use demonstrates that the surface area of the developed land patch is the largest in the first zone, as opposed to the surface area of the arable land patch. As far as the developed land is concerned, this means that large developed areas are dominant in the vicinity of the city. For arable land, this indicator illustrates the differences in the areas occupied by such lands: a single landscape patch used as arable land near 


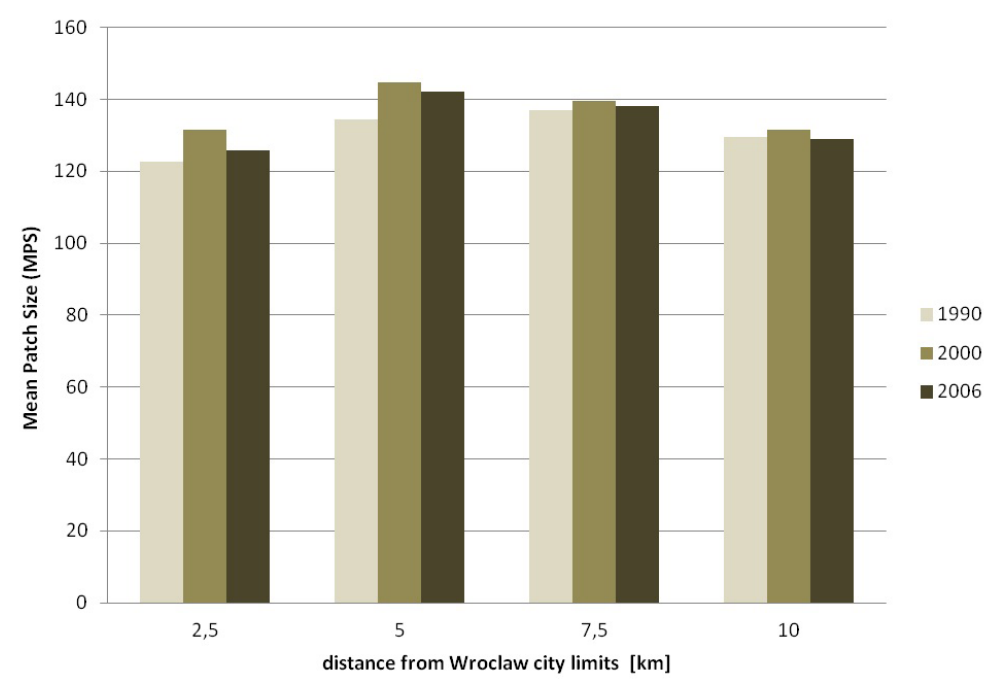

Fig. 5. Value of the MPS indicator for all types of land use in zones located at specific distances from the administrative limits of the city Wrocław in the years 1990, 2000 and 2006
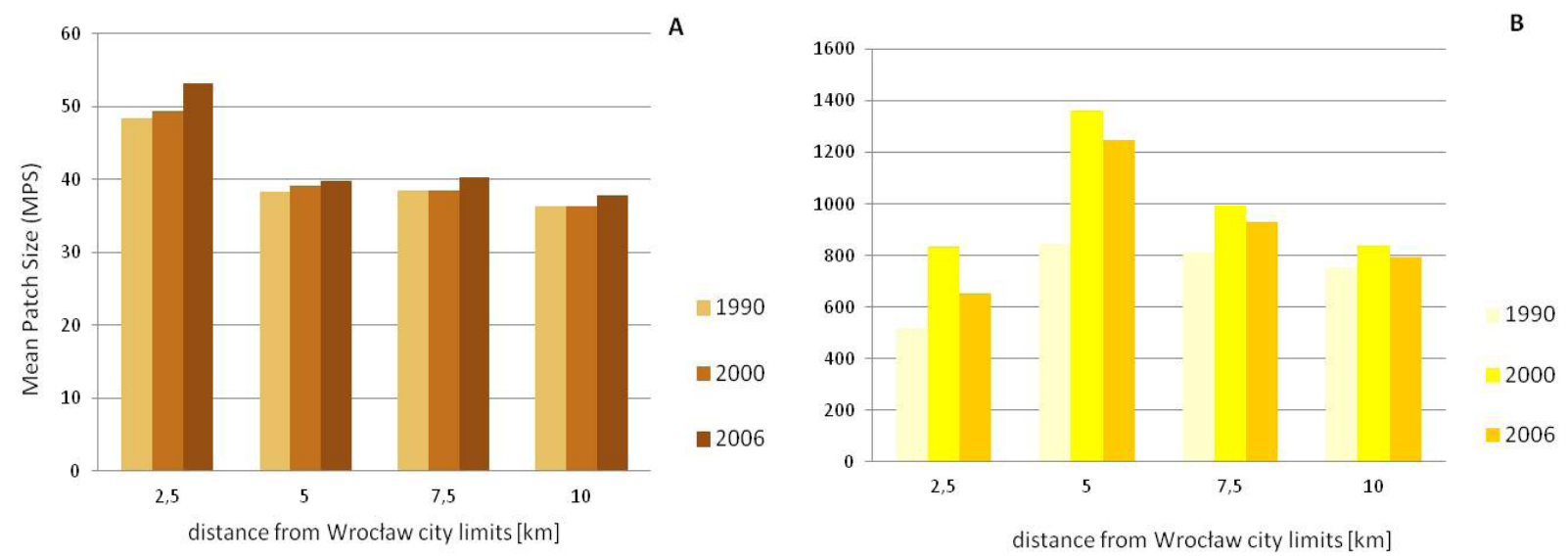

Fig. 6. Value of the MPS indicator for all developed land (A) and arable land (B) in zones located at specific distances from the administrative limits of the city Wrocław in the years 1990, 2000 and 2006

the city is, on the average, smaller than at a larger distance from the city. An issue that requires further analysis is the question why the MPS indicator was higher in 2000 than in 1990 and 2006, both for all forms of land use and for arable lands only. One of the possible explanations might be the process of consolidation of fragmented arable lands with the aim to change the type of their use later.

\section{Changes in the landscape indicators depending on the distance from the access roads to the central city}

The same research procedure as for the distance from the central city limits was applied to the distance from main access roads to the central city. The analyses conducted in the buffer zones along the main access roads to the city take into account the internal suburbanisation phenomenon (Kajdanek, 2011). The results of the analysis pertaining to the share of low intensity residential development, industrial and service facilities (Fig. 7), arable land and grasslands (Fig. 8) in the total surface area of individual zones are presented below.

The calculations demonstrate that a vast majority of suburban housing is located in the vicinity of main access roads to the city of Wrocław. A similar trend has been noted for the industrial and commercial areas. This phenomenon results from better communication with the city, which stimulates the growth of investments. The development of this type of land use in the analysed period was witnessed in all three zones discussed in the paper. It is also worth mentioning that as far as the buffer zones along access roads are concerned, the in- 


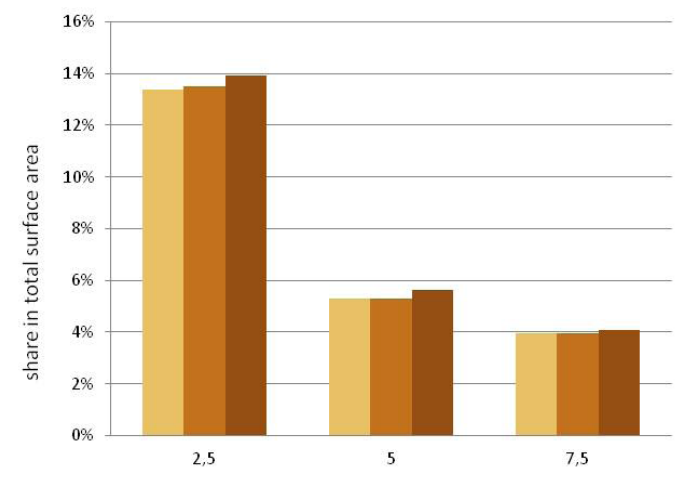

distance from main access roads to the city of Wrocław $[\mathrm{km}]$
A

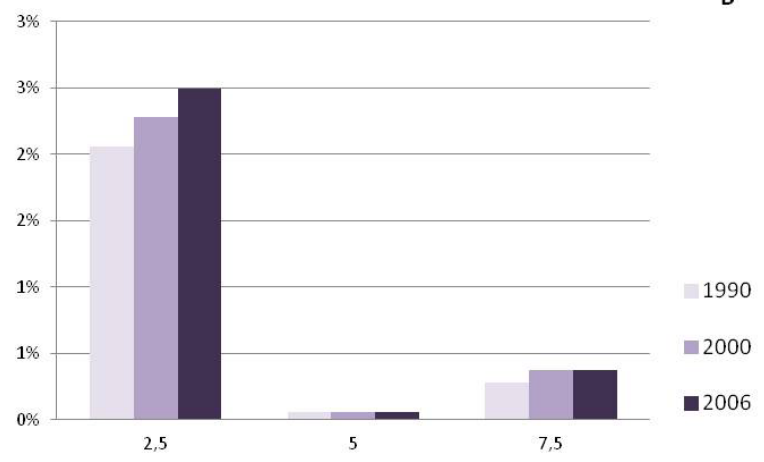

distance from main access roads to the city of Wrocław $[\mathrm{km}]$

Fig. 7. Share of low intensity residential development (A) and industrial and commercial areas (B) in the surface area of specific zones of distance from main access roads to Wrocław in the years 1990, 2000 and 2006
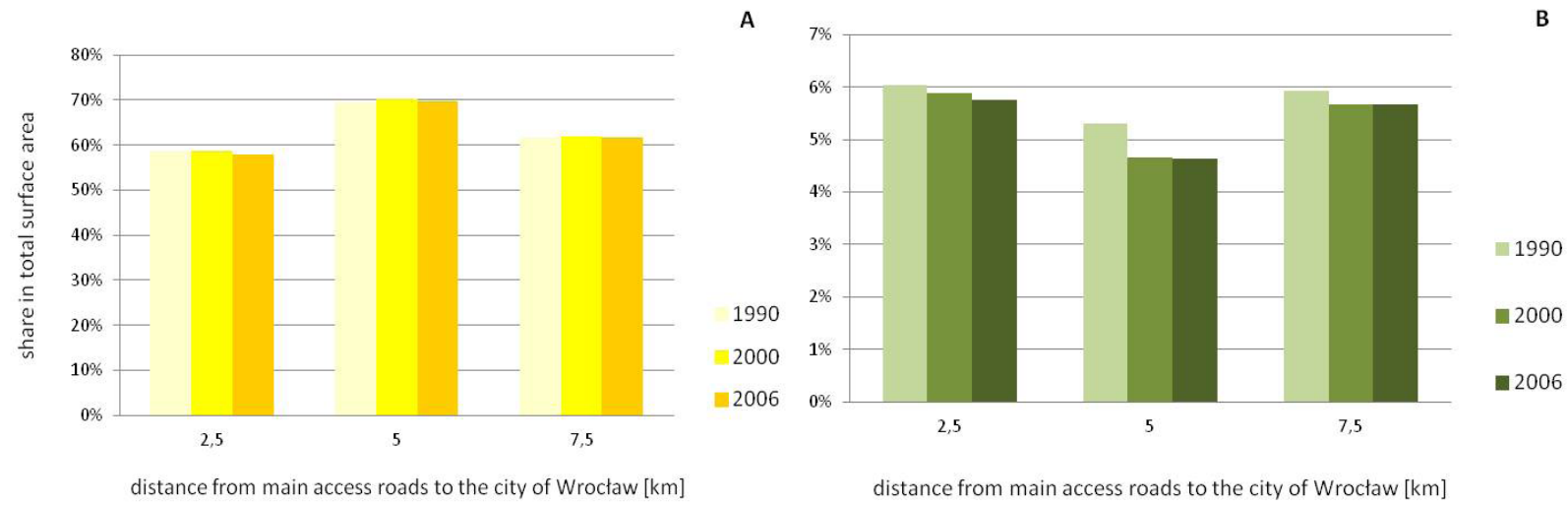

Fig. 8. Share of arable land (A) and grasslands (B) in the total surface area of zones located at specific distances from the main access roads to the city Wrocław in the years 1990, 2000 and 2006

crease in the share of residential areas is not as significant as it was in the case of the analysis of distance from city limits. Moreover, in the analysis of the influence of the first determining factor, the share of residential areas decreased gradually, from $12 \%$ in the first zone, reaching approx. $5 \%$ only in the fourth zone (7.5-10 $\mathrm{km})$. For distance from access roads, this share drops rapidly from over $13 \%$ in the first zone to slightly over $5 \%$ already in the second zone. The share of the industrial and commercial areas in the first zone exceeds $2 \%$, which is considerably higher than the values obtained in the analysis of distance from city limits $(0.8 \%)$.

As far as agricultural land (arable land and grasslands) is concerned, one may notice a growing decrease in time in the zones located closest to the roads. This results from the fact that the agricultural land nearest to the roads is being gradually occupied by other investments, which mainly involves suburban housing and industrial and commercial development. Similarly as in the analyses of the distance from city limits, these transformations are noticeable in all the analysed zones. As in the case of buffer zones around the city, the MPS indicator was analysed for zones of distance from roads. Its value was calculated both for all landscape patches divided according to their distance from the roads (Fig. 9), and, separately, for developed land and arable land (Fig. 10).

The average surface area of patches in specific zones of distance from the roads reveals a slightly different trend than in the buffer zones around city limits. The average landscape patch is larger in the proximity of main access roads to the city than the average patch in more distant areas. This means that landscape homogenisation has occurred in the direct vicinity of roads, resulting from an intensive development of similar ways of land use.

The results of the analyses of the MPS indicator for arable land and developed land are similar in both analyses. In the zone closest to the roads (as in the one nearest to the city) the 


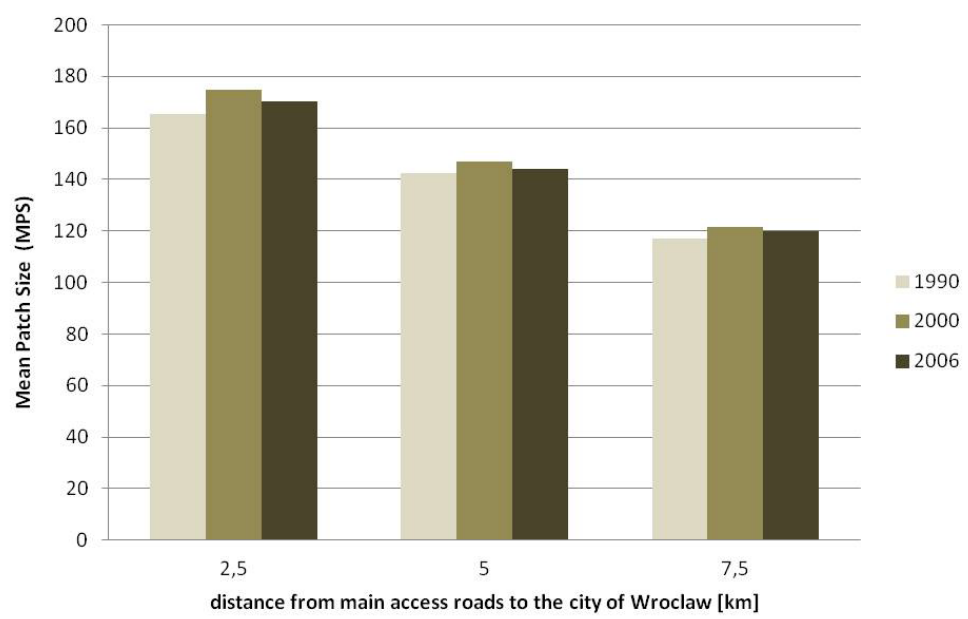

Fig. 9. Value of the MPS indicator for all types of land use in zones located at specific distances from the main access roads to the city Wrocław in the years 1990, 2000 and 2006
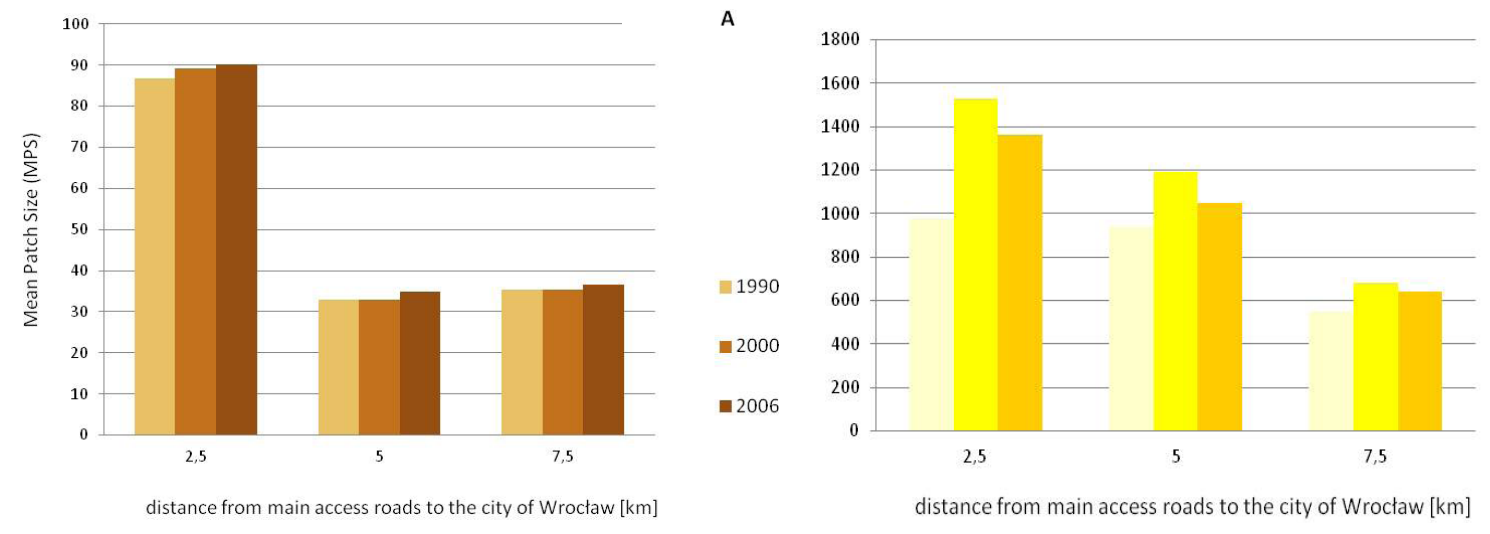

B

Fig. 10. Value of the MPS indicator for developed land (A) and arable land (B) in zones located at specific distances from the main access roads to the city Wrocław in the years 1990, 2000 and 2006

patch size is the largest. This means that the developed land constitutes consistent units and this manifests itself as low fragmentation of the landscape. As far as arable land near access roads is concerned, the patch size is the largest in the first zone (as opposed to the case of distance from city limits). The arable land patches become smaller with the increasing distance from roads, which results from other land use forms, such as forests and grasslands, thus enhancing the mosaic properties of landscape.

The mean patch size both for developed land and arable land is the largest in the proximity of access roads. This means that increased landscape homogenisation for both types of land use may be observed in the vicinity of these roads. For the residential areas, an MPS value of 85 was noted in the buffer zone up to $2.5 \mathrm{~km}$ from city limits. MPS values for zones located near roads are much higher. This results from a low number of patches in landscape, as both developed land and arable land cover large areas. As it was in the case of calculating the MPS indicator for buffer zones around administrative city limits, the highest values were noted in the year 2000, which should be investigated more thoroughly in further research.

\section{CONCLUSIONS}

The analyses of the share of specific types of land use and mean patch size in the zones established according to distance from the administrative limits of Wrocław and main access roads to the city revealed several characteristic spatial patterns. First of all, the share of suburban residential, service and industrial development in the total area decreases with the growing distance from the city and main 
roads, while the share of arable land and forests increases. In recent years, there has been a noticeable increase in the share of residential, industrial and service development in the zones adjacent to the city and access roads. At the same time, the distance from the city has a wider reach of impact stimulating the location of residential housing, which is confirmed by the gradual reduction in the share of residential areas to $5 \%$ in the zone up to $10 \mathrm{~km}$. However, the proximity of main access road is a stronger factor stimulating the development of housing areas, although its zone of impact is smaller and reaches only up to $2.5 \mathrm{~km}$. As for industrial and service development, these determining factors have a different effect. The influence of direct proximity of access roads on the placement of industrial and service areas is approx. three times stronger than that of the distance from city limits. This influence is beneficial for these functions of land use and it fosters this type of suburban areas development. The development of residential, service and industrial areas takes place at the expense of grasslands and arable land.

All the analyses discussed above confirm the growth in suburban development, especially in the direct vicinity of the city, and the resulting progressing homogenisation of landscape. Similar tendencies have been observed by other researchers, e.g. in the studies on the changes in landscape nature resulting from distance from main roads and the city centre of Warsaw (Roo-Zielińska et al., 2013), or in the research on the suburbanisation of the outskirts of Lublin (Przesmycka 2012) and Poznań (Szczepańska, Wilkaniec 2014). The two latter quoted works did not employ landscape indicators to describe the phenomenon of spreading of large cities. However, the authors used direct observations to draw the conclusion that the areas designated for residential development are increasing and that the spatial layout of suburban villages is subject to progressing transformations. Foryś and Putek-Szeląg (2014) demonstrated that the analysed area belongs to those regions of Poland, where urban agglomerations play a major role in the transformation of the real estate market. This confirms that it is justified to analyse the topic of monitoring the transformations of the functional and spatial structure of the suburban zone of Wrocław.

\section{Acknowledgments}

The authors would like to thank Ms Julia Jankowska for help in data processing, as part of the realisation of the research project NN305 384838, entitled: "Indicator assessment of the environmental changes caused by uncontrolled expansion of large cities", which was used in the present paper.

\section{REFERENCES}

1. Bajerowski T. (Ed.) 2008. Spatial management. Theoretical and practical aspects of forecasting the financial consequences of planning. Publisher UWM, Olsztyn (in Polish).

2. Christaller W. 1933. Central Places in Southern Germany. Jena (in German).

3. Cymerman R. 2012. Spatial planning for real estate appraisers, administrators and real estate brokers. Publisher Educaterra Sp. z o.o., Olsztyn (in Polish).

4. Foryś I., Putek-Szeląg E. 2014. Methods of linear ordering in estimation of potential of Polish market of agricultural property, Actual Problems of Economics, 151(1), 542-550.

5. Kajdanek K. 2011. Between a city and a country: Suburbanization in the Wrocław Metropolitan Area, Publisher NOMOS, Kraków (in Polish).

6. Kajdanek K. 2014. Newcomers vs. old-timers? Community, cooperation and conflict in the post-socialist suburbs of Wroclaw, Poland. Mobilities and Neighbourhood Belonging in Cities and Suburbs, 182-199.

7. Kazak J., van Hoof J., Szewrański S. 2017. Challenges in the wind turbines location process in Central Europe - The use of spatial decision support systems, Renewable and Sustainable Energy Reviews, Vol. 76, Sept. 2017, 425-433.

8. Kazak J., Chalfen M., Kamińska J., Szewrański S., Świąder M. 2018. Geo-Dynamic Decision Support System for Urban Traffic Management, (Ed.) Ivan, I; Horak, J; Inspektor, T: GIS Ostrava 2017 - Dynamics in GIscience, Lecture Notes in Geoinformation and Cartography, 195-207.

9. Przesmycka N. 2012. The cultural Landscape of new Suburbia of Lublin, Teka (Archives) of the Commission of Architecture, Urban Planning and Landscape Studies. - OL PAN, VIII/1, 93-103 (in Polish).

10. Przybyła, K., Kulczyk-Dynowska, A., Kachniarz, M. 2014. Quality of life in the regional capitals of Poland, Journal of Economic Issues, 48(1), 181-196.

11. Roo-Zielińska E., Solon J., Degórski M. 2013. The use of ecological indicators to assess the state and changes in the geographical environment, http://pbc.up.krakow.pl/Content/3278/49-87ka. 
pdf, access date: 6.07.2013 (in Polish).

12. Staszewska S. 2012. Urban Transformations of Rural Settlement Units of Suburban Areas. Regional Barometer No. 4(30), 53-68 (in Polish).

13. Szachowicz U., Niedźwiecka-Filipiak I. 2007. Selected Problems of fuctional and spatial Chages in suburban Area Communes - an Example of the Dobrzeń Wielki Comune, Woda-ŚrodowiskoObszary Wiejskie (Water-Environment-Rural areas), Publisher Institute of Technology and Life Sciences in Falenty Vol. 7, iss. 2b (21), 185-194 (in Polish).

14. Szewrański, S., Kazak, J., Szkaradkiewicz, M., Sasik, J. 2015. Flood risk factors in suburban area in the context of climate change adaptation policies - Case study of Wroclaw, Poland. Journal of Ecological Engineering, 16 (2), 13-18.
15. Szczepańska M., Wilkaniec A. 2014. Transformation of cultural landscape of selected villages in the suburban zone of Poznań, Rural Studies, Vol. 35: Regional Dimension of Changes in Polish Rural Areas - Social and Environmental Aspect, 45-59 (in Polish).

16. Świąder M., Szewrański S., Kazak J. 2016. Spatial-Temporal Diversification of Poverty in Wroclaw, Procedia Engineering, Vol. 161, 1596-1600.

17. Wang T., Han Q., de Vries B. 2017. A semi-automatic neighborhood rule discovery approach, Applied Geography, Vol. 88, 73-83.

18. Zathey M. 2005. Suburbanization processes in the Wroclaw urban area - suburbial zone of Wroclaw. Piotr Lorens (ed.) Problems of suburbanization. Urbanista, 191-199 (in Polish) 